Elżbieta Małuszyńska ${ }^{1}$, Piotr Stefański ${ }^{2}$, Przemysław Matysik $^{2}$, Zygmunt Nita $^{2}$, Krystyna Rybka $^{1 *}$

${ }^{1}$ Plant Breeding and Acclimatization Institute - National Research Institute, Radzików, 05-870 Błonie, Poland; ${ }^{2}$ Plant Breeding Strzelce Ltd. Co., ul. Główna 20, 99-307 Strzelce, Poland; ${ }^{*}$ author for correspondence

\title{
DOES ILLUMINATION OF NON-MATURE CEREAL KERNELS DURING DRYING AFFECT THE GERMINATION ABILITY?
}

\begin{abstract}
The principle of the market competitiveness of breeding companies implicates a fast production of new varieties. One way to achieve this goal brings single seed descent (SSD) methodology, which requires kernels collection (18-23 days after pollination), fast drying amd germination. Seed drying conditions influence the germination. In present work the influence of lightings: Sanyo LED and incandescent lamp vs. dark control during drying were studied. Kernels were harvested 18 and 23 days after pollination of wheat, triticale and barley cultivars grown in the same field experiment in 2015 . It was found that: - the germination ability of non-mature kernels depends on all studied factors: lighting during drying, terms of harvesting and the interaction light * term; • non mature kernelsare more sensitive to drying conditions; • lighting during seeds drying can have a positive effect on ability to germination; • for breeding practice it would be better to harvest kernels at 23 DAF and dry them at room conditions under incandescent lamp.
\end{abstract}

Key words: barley (H. vulgare, L.), LED lighting, triticale (x Triticosecale), wheat (T. aestivum, L.)

\section{INTRODUCTION}

In some processes of cereal breeding, such as Single Seed Descent (SSD), propagation of non-mature kernels is required for 5-6 generations in order to develop pure lines of genetically and phenotypically stable homozygous materials. This is the consequence of an effort to shorten the breeding processes as much as possible. A common practice in such a procedure is collecting kernels as early as possible to get the next generation in the

Communicated by Grzegorz Żurek 
same calendar year. It is desirable to obtain 3 and even, in the case of spring forms, 4 generations per year. To achieve that the non-mature kernels must be collected, dried, germinated and reproduced.

The ability of non-mature seeds to germination is dependent on their stage of development (Bentsink and Koornneef, 2008; Bewley and Black, 1994). Normally all cereal kernels must undergo the phase of physiological maturation and dehydration prior to germination. However, after enforced drying, even immature kernels achieve the ability for germination, which became possible even in the proembryo developmental stage, 5-7 days after pollination (DAP) (Grzesiuk and Kulka, 1981). The lasting of the germination takes usually dozens of days; in the case of spring barley or winter wheat this period lasts more than 50 days and seedlings obtained in this way grow poorly (Grzesiuk and Kulka, 1981). In 9-15 DAP when kernels are in the early stage of milk maturity (sometimes called green) and the water content is in the range $40-65 \%$, germination is faster and developed plants grow normally and are capable for reproducing (Lityński, 1982).

The non-mature cereal kernels get the maximum ability to germination at the beginning of wax maturity when the hydration is in the range $25-40 \%$. It was observed that non-mature wheat kernels on 6 DAP were already able to germination, however, the acceptable germination was obtained at 18 DAP. Also it was found that the length of drying period improves gradually the germination (Balla, 1979). For wheat there are two intervals of low germability during kernels development, the first when undried ones are unable to germinate, followed by an increase in germability, coinciding with natural decrease in moisture content. After this short period of relatively high ability to germination, a second phase of low germability appears, that begins when seeds are losing moisture during maturation stage. This phase is considered to be the true dormancy (Bewley and Black, 1994). Also in triticale, fast germination was observed from 15 DAP, with a maximum between 18 and 25 DAP depending on the season and variety, followed by a reduced germination period lasting up to 48-52 DAP, when kernels gained the maximum dry weight (Pokojska and Grzelak, 1994). Whereas in malting barley, which germination is important not only in the seed propagation but also in malt production, it was found that seeds at 1625 DAP were characterized by high germination and satisfactory properties for malting that is, the rate and uniformity of germination (Koornneef et al., 2002).

In cereal breeding practice the question arises whether the lighting used during the process of non-mature kernels drying can influence positively on germination. The impact of light on key processes of plants growth and development are known (Kopcewicz, 1980) and the transitions from seed to seedling have been recently reviewed by Warpeha and Montgomery (2016). The regulation signals of light are mediated by photoreceptors. Phyto- 
chromes and cryptochromes, sensitive to red/far red as well as blue/ ultraviolet lights, respectively, percept the light signals which integrated with hormones action impact on seed germination and seedling development (Lau and Deng, 2010; Warpeha and Montgomery, 2016). In Arabidopsis thaliana and Lactuca sativea, white and red lights promote germination while the far-red light inhibits it (Argyris et al., 2008; Gong 2014; Piskurewicz et al. 2009). Analysis of gene expression in imbibed barley kernels revealed that different genes of ABA metabolism are targeted by the white light (Gubler et al., 2008).

Current publications on the impact of lighting on processes of nonmature seeds drying are unknown to the authors of this article. The former work by Lityński and Urbaniak (1958) demonstrated that 2 years long storage of cucumber and cabbage seeds under the orange-yellow light had the positive effect on seeds germination as well as the white, blue-violet or orange-yellow illumination on carrot, spinach and cabbage seeds.

The purpose of our preliminary studies is to evaluate if illumination of non-mature kernels during drying affect to germination.

\section{MATERIALS AND METHODS}

Materials consisted kernels of selected cultivars of 3 species: wheat ( $T$. aestivum L.) spring cultivars: Raweta and Rospuda and winter cultivars: Bamberka and Ostka Strzelecka; triticale (x Triticosecale Wittm. ex A. Camus) spring cultivars: Andrus and Milewo and winter cultivars: Borowik and Pigmej; barley (H. vulgare L.) spring cultivars: Rubaszek and Suweren. Winter barley was not studied due to much earlier flowering time. The experimental materials were collected form field plots located in Plant Breeding and Acclimatization Institute-National Research Institute in Radzików (central Poland; GPS coordinates: N 52.211754, E 20.631954). Cereals were sown in accordance with the agrotechnical terms. At time of pollination 40 ears were marked prior to collection 18 as well as 23/24 days later. Thirty ears (in case of small ears 35) of each cultivar were taken from experimental plots and in the laboratory the top and bottom of each ear were cut off and thrown away to hulled the kernels from the remained central part of the ear. Three different variants of kernel drying were used: (1) Sanyo plant growing chamber model MLR-350HTin darkness at $25^{\circ} \mathrm{C}$ and (2) with Sanyo LED lighting in as well as (3) room conditions, as used by breeders, in day light supported by incandescent lamp and in temperature in range $22-25^{\circ} \mathrm{C}$. Control kernels were not dried. Each experimental variant consisted 190 kernels. During drying the kernels were weighed 2 times per day (at 8.00 AM and 2.30 PM). Drying was terminated, when the weight of the kernels did not change. The moisture content of studied kernels was calculated basing on their fresh weight. Dried kernels were put between 2 
pieces of filter paper moistened with $0.2 \% \mathrm{KNO}_{3}$ to test germination . The evaluation was conducted in accordance with ISTA Rules (2015) after 8 (marked in Tables as 18-1 and 23-1) and 15 days after sowing (marked as 18-2 and 23-2) and the germination was expressed in percentages. For each cultivar 3 $\times 50$ kernels were used. For light spectra measurements the GL Spectis 1.0 touch spectroradiometer (GL Optic R\&D Center Ltd., Puszczykowo, Poland) was used. The Statistica software (StatSoft Polska, Ltd., Kraków, Poland) was used for analysis of variance (ANOVA) and LSD test for the evaluation the significance of differences.

\section{RESULTS AND DISCUSSION}

In this experiment two variants of lighting were used: Sanyo LED grow lighting and office room day light supported by incandescent lamp, as used by breeders in common practice. Control samples were not dried. Both artificial light sources emitted similar warm light as expressed in Kalvin degree (about 3000) despite different spectra. Sanyo LED illuminator was characterized by 2 main peaks of blue and red lights, and total radiance of about $4.5 \mathrm{~W} / \mathrm{m}^{2}$ with maximum average color peak at about $600 \mathrm{~nm}$, whereas incandescent lamp radiation was about 4 times stronger with color peak shifted towards red waves (Fig. 1). Also the Photosynthetic Photon Flux Density (PPFD) and Photosynthetic Active Radiation (PAR) were about 3 times higher under the incandescent lamp. Lightings used for drying were characterized by specific parameters lower by at least an order of magnitude, than those required for plants growing (Ge et al. 2011; Tibbitts et al. 1983) and were in accordance with requirements for seed germination (ISTA 2015). Chosen conditions corresponded to breeders practice of drying although cereals germination is indispensable on light. The main difference between used illuminators was associated with the spectrum of light: more blue light waves from Sanyo source in contrast to more red light waves from incandescent lamp.

Light spectrum is one of the most important factor affecting the photomorphogenesis in plants. Different proportions of red/far red, blue/violet and blue/red light spectra are recognized by phytochromes and cryptochromes (Kong and Okajima, 2016). The red light and red/far red signals detected by phytochromes, which presently are known as existing in 5 forms, influence seed germination and seedling de-etiolation. Blue and ultraviolet lights are percepted by 2 cryptochromes, phototropins and UVR8 receptor and influence de-etiolation, phototropism and inhibition of dicotyledons hypocotyl elongation as reviewed by Warpeha and Montgomery (2016). In present studies the influence of light quality during non-mature kernels drying on subsequent seed germination was detected. 


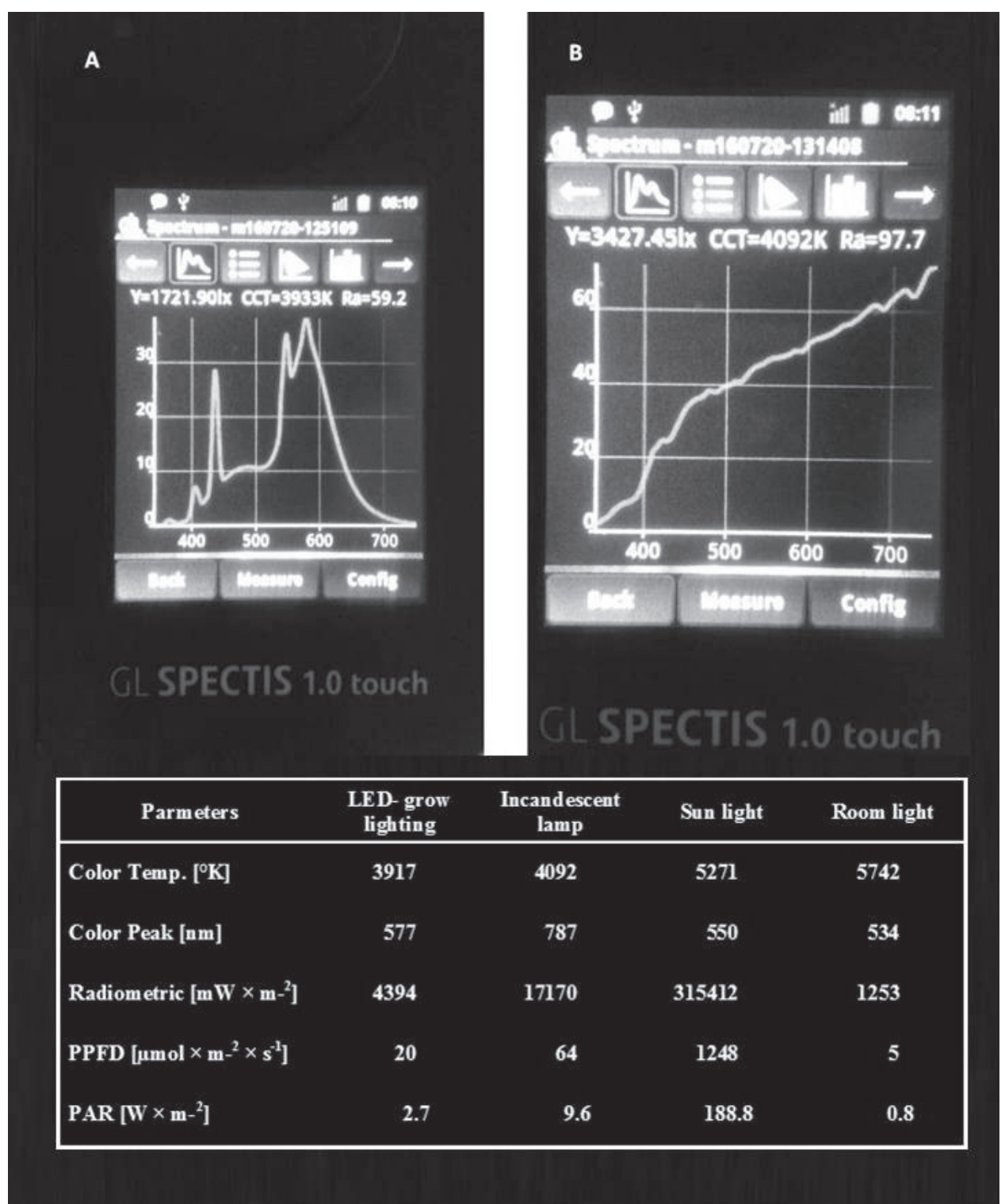

Fig. 1. The spectra (A) LED grow lighting and (B) incandescent lamp used for non-mature grains drying and their parametric characteristics in comparison with sun and room lights 
Table 1.

Length of drying [days] and moisture content [\%] of non-mature wheat, triticale and barley kernels harvested at 18 and 23/24 days after pollination which were dried: in Sanyo thermostat at $25^{\circ} \mathrm{C}$ in darkness; in thermostat at $25^{\circ} \mathrm{C}$ under LED grow lighting and in room conditions at $22-25^{\circ} \mathrm{C}$ under incandescent lamp. Results are expressed in [\%] and have been rounded to integer numbers

\begin{tabular}{|c|c|c|c|c|c|c|}
\hline \multirow{3}{*}{ Cultivar } & \multicolumn{4}{|c|}{ Sanyo thermostat } & \multirow{2}{*}{\multicolumn{2}{|c|}{$\begin{array}{l}\text { Room conditions } \\
\text { Incandescent lamp }\end{array}$}} \\
\hline & \multicolumn{2}{|c|}{ Darkness } & \multicolumn{2}{|c|}{ LED grow lighting } & & \\
\hline & $\begin{array}{c}\text { Days of } \\
\text { drying }\end{array}$ & $\begin{array}{c}\text { Moisture } \\
\text { content } \\
{[\%]}\end{array}$ & $\begin{array}{c}\text { Days of } \\
\text { drying }\end{array}$ & $\begin{array}{c}\text { Moisture } \\
\text { content } \\
{[\%]}\end{array}$ & $\begin{array}{c}\text { Days of } \\
\text { drying }\end{array}$ & $\begin{array}{c}\text { Moisture } \\
\text { content } \\
{[\%]}\end{array}$ \\
\hline \multicolumn{7}{|c|}{ 18DAF } \\
\hline \multicolumn{7}{|c|}{ Spring wheat } \\
\hline Raweta & 7 & 69.0 & 7 & 69.5 & 6 & 69.1 \\
\hline Rospuda & 6 & 69.1 & 5 & 68.5 & 5 & 68.4 \\
\hline \multicolumn{7}{|c|}{ Winter wheat } \\
\hline Bamberka & 6 & 64.5 & 6 & 64.1 & 6 & 63.1 \\
\hline Ostka Strz. & 6 & 65.9 & 6 & 65.7 & 6 & 63.5 \\
\hline \multicolumn{7}{|c|}{ Spring triticale } \\
\hline Andrus & 7 & 69.3 & 6 & 70.0 & 6 & 68.9 \\
\hline Milewo & 7 & 68.9 & 6 & 68.4 & 6 & 67.2 \\
\hline \multicolumn{7}{|c|}{ Winter triticale } \\
\hline Borowik & 7 & 65.1 & 7 & 64.3 & 7 & 64.4 \\
\hline Pigmej & 6 & 62.9 & 6 & 63.6 & 6 & 64.4 \\
\hline \multicolumn{7}{|c|}{ Spring barley } \\
\hline Rubaszek & 6 & 58.1 & 6 & 58.9 & 6 & 56.9 \\
\hline Suweren & 6 & 54.3 & 7 & 55.4 & 7 & 55.9 \\
\hline \multicolumn{7}{|c|}{$23 / 24 \mathrm{DAF}$} \\
\hline \multicolumn{7}{|c|}{ Spring wheat } \\
\hline Raweta & 5 & 55.6 & 6 & 55.3 & 6 & 54.8 \\
\hline Rospuda & 5 & 56.7 & 6 & 56.7 & 6 & 55.9 \\
\hline \multicolumn{7}{|c|}{ Winter wheat } \\
\hline Bamberka & 7 & 56.5 & 7 & 55.9 & 7 & 56.6 \\
\hline Ostka Strz. & 7 & 55.8 & 7 & 57.1 & 7 & 56.8 \\
\hline \multicolumn{7}{|c|}{ Spring triticale } \\
\hline Andrus & 5 & 59.0 & 5 & 59.6 & 6 & 59.5 \\
\hline Milewo & 7 & 56.9 & 7 & 56.3 & 7 & 55.8 \\
\hline \multicolumn{7}{|c|}{ Winter triticale } \\
\hline Borowik & 6 & 58 & 6 & 58.5 & 7 & 58.6 \\
\hline Pigmej & 7 & 55.9 & 7 & 54.6 & 7 & 55.2 \\
\hline \multicolumn{7}{|c|}{ Spring barley } \\
\hline Rubaszek & 6 & 52.2 & 6 & 51.6 & 5 & 52.1 \\
\hline Suweren & 7 & 48.4 & 7 & 49.4 & 5 & 47.6 \\
\hline
\end{tabular}


Kernels were collected in 2 terms, in accordance with breeding practice: 18 and 23 DAP. Experimental material was differentiated by time required for drying as well as by moisture content. Kernels collected in the $1^{\text {st }}$ and $2^{\text {nd }}$ terms needed in average 6 days to get the constant weight: from 5 to 7 days. It is interesting that evidently the winter wheat harvested in $2^{\text {nd }}$ term required one day more to get the constant weight than in $1^{\text {st }}$ term, independently from lighting as well as the spring wheat kernels harvested in $2^{\text {nd }}$ term dried in darkness shorter than under lighting. These small differences in the time required to obtain a constant weight by kernels the most likely could result from differences in sugars and proteins content and polymers composition, which affect the water holding capacity (Rybka, 1994; Rybka, et al., 1988; Saulnier, et al., 2012). The seed moisture content depended on the term of harvest. The average water content harvested 18 DAP was $65 \%$, whereas in kernels harvested in $2^{\text {nd }}$ term contained $55 \%$ of water (Table 1 ). The variability of the trait was low and the coefficient of variation was $<2 \%$ in each group of objects (not shown).

Table 2

Results of analysis of variance (ANOVA). F-values for the germination after 8 days and germination after 15 days Significance of the effects were marked as $* * *$ for- $p>99 \%$ and $* *$ for $p>95 \%$ respectively

\begin{tabular}{|c|c|c|c|c|c|c|}
\hline \multirow{2}{*}{ Cultivar } & \multicolumn{3}{|c|}{ The first count } & \multicolumn{3}{|c|}{ The second count } \\
\hline & Light & Term & Light $\times$ term & Light & Term & Light $\times$ term \\
\hline Raweta & $15.2 * * *$ & $392.1 * * *$ & 1.24 & $6.0 * *$ & $160.3 * * *$ & $5.6^{* *}$ \\
\hline Bamberka & 0.27 & 3.32 & 0.07 & 1.15 & 3.20 & 0.40 \\
\hline Andrus & $9.9 * *$ & $21.1 * * *$ & $17.4 * * *$ & $21.2 * * *$ & $25.6^{* * *}$ & 3.7 \\
\hline Rubaszek & $272.9 * * *$ & $106.3^{* * *}$ & $87.2 * * *$ & $73.8 * * *$ & $75.2 * * *$ & 0.06 \\
\hline Borowik & 1.26 & $18.7 * * *$ & $5.6 * *$ & 0.96 & $18.3^{* *}$ & $43.7 * * *$ \\
\hline Milewo & 1.33 & $182.53 * * *$ & 0.21 & $9.31 * *$ & $296.35 * * *$ & 0.16 \\
\hline OstkaStrz. & $5.43 * *$ & $3630.0^{* * *} *$ & 2.70 & 3.53 & $344.62 * * *$ & 3.46 \\
\hline Pigmej & 0.83 & $240.99 * * *$ & $3.97 * *$ & $6.12 * *$ & $140.35^{* * * *}$ & $15.78 * *$ \\
\hline Rospuda & $4.13 * *$ & $744.73 * * *$ & 0.22 & $6.26 * *$ & $877.56^{* * * *}$ & 2.56 \\
\hline Suweren & $307.40 * * *$ & $77.40 * * *$ & $95.81 * * *$ & $492.86^{* * *}$ & 4.5 & $225.18 * * *$ \\
\hline
\end{tabular}

The ability to germination was determined in dried seeds as well as in control, non-dried ones. The meaning of the ability to germination indicates, capacity to form the normal seedlings under conditions optimal for seed germination i.e. at a suitable temperature, humidity and on a suitable substrate, evaluated after a certain number of days in accordance with the methodology specified in the ISTA Rules (2015). In present experiment kernels were germinated for 8 or 15 days. When harvested at the term of the physiological maturity the kernels were often in the state of post-harvest dormancy, which in the case of winter cultivars, is an undesirable trait due to rapid and equal germination required by modern agricultural technology. On the other hand some degree of dormancy is advantageous, at least during the cereal kernels development, since it prevents against the pre-harvest sprouting, i.e. germination on the ear on the parental plant (Masojć and Milczarski, 
2009; Munkvold et al., 2009). The experiments run in order to assess germination ability should be carried out with regard to those two physiological characteristics; they cannot be too short and breaking of the possible dormancy must be taken account . To break the dormancy a variety of methods can be used, e.g.: chilling for few days of sown kernels in temperatures below $10^{\circ} \mathrm{C}$, as well as moistening of the substrate used for germination with a $\mathrm{KNO}_{3}$ solutions or the simultaneous usage of several methods in the way described by ISTA Rules (ISTA 2015).

Table 3

Ggermination of non-mature wheat, triticale and barley kernels after 8 and 15 days harvested at 18 and 23 days after, described in table header as $18 / 8,18 / 15,23 / 8$ and 23/15 respectively; dried:in thermostat at $25^{\circ} \mathrm{C}$ in darkness; in thermostat at $25^{\circ} \mathrm{C}$ under $\mathrm{LED}$ grow lighting and in room conditions $22-25^{\circ} \mathrm{C}$ under incandescent lamp. Results are expressed in [\%] and have been rounded to integer numbers

\begin{tabular}{|c|c|c|c|c|c|c|c|c|}
\hline \multicolumn{9}{|c|}{ Ability to germination [\%] } \\
\hline \multirow{3}{*}{ Terms } & $18-1$ & $18-2$ & $23-1$ & $23-2$ & $18-1$ & $18-2$ & $23-1$ & $23-2$ \\
\hline & \multicolumn{8}{|c|}{ Spring wheat } \\
\hline & \multicolumn{4}{|c|}{ Raweta } & \multicolumn{4}{|c|}{ Rospuda } \\
\hline Darkness & $36 a$ & $66 \mathrm{a}$ & $82 \mathrm{a}$ & $98 \mathrm{a}$ & $12 \mathrm{a}$ & $52 \mathrm{~b}$ & $70 \mathrm{a}$ & $96 a$ \\
\hline LED growlighting & $22 \mathrm{a}$ & $50 \mathrm{~b}$ & $68 b$ & $94 \mathrm{a}$ & $10 \mathrm{a}$ & $50 \mathrm{~b}$ & $66 \mathrm{a}$ & $94 \mathrm{a}$ \\
\hline \multirow[t]{3}{*}{ Incandescent lamp } & $18 \mathrm{a}$ & $70 \mathrm{a}$ & $72 \mathrm{ab}$ & $94 \mathrm{a}$ & $16 \mathrm{a}$ & $60 \mathrm{a}$ & $74 \mathrm{a}$ & $96 a$ \\
\hline & \multicolumn{8}{|c|}{ Winter wheat } \\
\hline & \multicolumn{4}{|c|}{ Bamberka } & \multicolumn{4}{|c|}{ Ostka Strzelecka } \\
\hline Darkness & $6 a$ & $62 \mathrm{a}$ & $4 a$ & $52 \mathrm{a}$ & $8 b$ & $54 b$ & $86 a$ & $98 \mathrm{a}$ \\
\hline LED growlighting & $6 a$ & $52 \mathrm{a}$ & $2 \mathrm{a}$ & $50 \mathrm{a}$ & $10 \mathrm{ab}$ & $64 \mathrm{a}$ & $81 \mathrm{a}$ & $98 \mathrm{a}$ \\
\hline \multirow[t]{3}{*}{ Incandescent lamp } & $6 a$ & $58 \mathrm{a}$ & $4 a$ & $50 \mathrm{a}$ & $14 \mathrm{a}$ & $64 \mathrm{a}$ & $86 a$ & $98 \mathrm{a}$ \\
\hline & \multicolumn{8}{|c|}{ Spring triticale } \\
\hline & \multicolumn{4}{|c|}{ Andrus } & \multicolumn{4}{|c|}{ Milewo } \\
\hline Darkness & $12 b$ & $46 a$ & $16 \mathrm{a}$ & $64 a$ & $2 b$ & $28 b$ & $24 \mathrm{a}$ & $72 \mathrm{ab}$ \\
\hline LED growlighting & $10 \mathrm{a}$ & $38 \mathrm{a}$ & $6 b$ & $42 b$ & $4 a$ & $30 \mathrm{~b}$ & $24 \mathrm{a}$ & $78 \mathrm{a}$ \\
\hline \multirow[t]{3}{*}{ Incandescent lamp } & $2 \mathrm{c}$ & $52 \mathrm{a}$ & $12 \mathrm{ab}$ & $72 \mathrm{a}$ & $4 a$ & $38 b$ & $28 \mathrm{a}$ & $82 \mathrm{a}$ \\
\hline & \multicolumn{8}{|c|}{ Winter triticale } \\
\hline & \multicolumn{4}{|c|}{ Borowik } & \multicolumn{4}{|c|}{ Pigmej } \\
\hline Darkness & $20 \mathrm{~b}$ & $76 a$ & $14 \mathrm{a}$ & $92 \mathrm{a}$ & $52 \mathrm{a}$ & $76 b$ & $92 \mathrm{a}$ & $98 \mathrm{a}$ \\
\hline LED growlighting & $20 \mathrm{~b}$ & $74 a$ & $18 \mathrm{a}$ & $88 \mathrm{a}$ & $42 \mathrm{a}$ & $64 c$ & $94 a$ & $98 \mathrm{a}$ \\
\hline \multirow[t]{3}{*}{ Incandescent lamp } & $26 a$ & $76 a$ & $14 \mathrm{a}$ & $92 \mathrm{a}$ & $46 \mathrm{a}$ & $82 \mathrm{a}$ & $82 a$ & $90 \mathrm{a}$ \\
\hline & \multicolumn{8}{|c|}{ Spring barley } \\
\hline & \multicolumn{4}{|c|}{ Rubaszek } & \multicolumn{4}{|c|}{ Suweren } \\
\hline Darkness & $2 \mathrm{c}$ & $12 \mathrm{c}$ & $2 \mathrm{c}$ & $46 a$ & 0 & $6 b$ & $2 b$ & $50 \mathrm{a}$ \\
\hline LED growlighting & $58 \mathrm{a}$ & $66 \mathrm{a}$ & $20 \mathrm{a}$ & $32 b$ & $70 \mathrm{a}$ & $94 a$ & $22 \mathrm{a}$ & $22 b$ \\
\hline Incandescent lamp & $18 b$ & $22 b$ & $14 \mathrm{~b}$ & $52 \mathrm{a}$ & 0 & $10 \mathrm{~b}$ & $2 b$ & $52 \mathrm{a}$ \\
\hline
\end{tabular}

In present experiment $0.2 \% \mathrm{KNO}_{3}$ was used for dormancy breaking (ISTA, $2015)$ and the ability to germination was evaluated 8 and 15 days after sowing $\left(1^{\text {st }}\right.$ 
and $2^{\text {nd }}$ term) (Table 2 and Table 3 ). The control kernels, which were not dried, did not germinate during the time set for the experiment (not shown). It was to be expected, since the ability to germination of non-mature seeds increases gradually with drying (Grzesiuk and Kulka 1988; Balla, 1979).

Analysis of variance of kernels ability to germination after drying and determination of homogeneous groups by Fisher test indicated interactions between light, term and light $\times$ term factors (Table 2 ). The germination of spring wheat Rospuda evaluated at the second term was $10 \%$ higher for kernels dried under the lamp as compared to other drying conditions (Table 3). Whereas winter wheat Ostka Strzelecka was characterized by a higher germination ability after 8 days when dried under the incandescent lamp. Kernels of both spring as well as winter wheat harvested in the second term, 23 days after pollination, showed no differences in germination regardless to drying conditions. Both of the triticale spring varieties, in both harvesting terms, were characterized by higher germination ability, when the kernels were dried under a lamp, although the differences were statistically not significant. In winter triticale the lamp had a stimulating effect visible as better germination of Borowik kernels collected at 18 DAP and evaluated after 8 days and Pigmej kernels collected at 18 DAP and evaluated after 15 days. On the other hand both spring barley varieties showed positive reaction for drying under lightings rich in blue waves. Detected differences may arise from the fact that barley seed morphology is different than wheat and triticale due to husks overgrown the kernel (Grzesiuk and Kulka, 1988).

\section{CONCLUSIONS:}

The germination ability of non-mature cereal kernels depends on all studied factors: lighting during seeds drying, terms of harvesting and the interaction light $\times$ term.

Less maturated seeds are more sensitive to drying conditions; illumination during drying can have a positive effect on seed quality.

For breeding practice it would be profitable to harvest kernels at $23 \mathrm{DAF}$ and dry them at room conditions under incandescent lamp.

\section{ACKNOWLEDGEMENTS:}

This work was supported by the National Centre for Research and Development, Poland (grant PBS3/B8/19/2015). Results are planned to be a part of PhD thesis of Piotr Stefański, MSci. eng. The authors declare any actual or potential conflict of interest. 


\section{REFERENCES}

Argyris, J., Dahal, P., Hayashi, E., Still, D.W., Bradford, K.J., 2008. Genetic Variation for Lettuce Seed Thermoinhibition Is Associated with Temperature-Sensitive Expression of Abscisic Acid, Gibberellin, and Ethylene Biosynthesis, Metabolism, and Response Genes. Plant Physiol. 148, 926-947.

Balla, L., 1979.The germination of immature winter wheat seeds. II. Cereal Res. Com. 7, 103-111.

Bentsink, L., Koornneef, M., 2008. Seed Dormancy and Germination. The Arabidopsis Book / American Society of Plant Biologists 6, e0119.

Bewley, J.D., Black, M., 1994. Seeds; Physiology of development and germination. New York: Plenum Press.

Ge, S., Smith, R.G., Jacovides, C.P., Kramer, M.G., Carruthers, R.I., 2011. Dynamics of photosynthetic photon flux density (PPFD) and estimates in coastal northern California. Theor. Appl. Climatol. 105, 107-118.

Gong, X., Li, C., Zhou, M., Bonnardeaux, Y., Yan, G., 2014. Seed dormancy in barley is dictated by genetics, environments and their interactions. Euphytica 197, 355-368.

Grzesiuk S. Kulka K. 1981. Kiełkowanie nasion o różnym stopniu dojrzałości. In: Fizjologia i biochemia nasion. PWRiL Warszawa pp. 400-402 (in Polish)

Grzesiuk, S., Kulka, K., 1988. Zależność kiełkowania ziarniaków od ich właściwości i wpływu czynników środowiskowych. In: Biologia ziarniaków zbóż. Grzesiuk S. Kulka K. (ed.) PWN Warszawa. pp. 445-455 (in Polish)

Gubler, F., Hughes, T., Waterhouse, P., Jacobsen, J., 2008. Regulation of Dormancy in Barley by Blue Light and After-Ripening: Effects on Abscisic Acid and Gibberellin Metabolism. Plant Physiol. 147, 886-896.

ISTA. International Seed Testing Association. 2015. ISTA Rules. Polish edition. Małuszyńska, E., Wiewióra, B., Rybka, K., Drzewiecki, J., Boros, L., Szydłowska, A, (ed.), IHAR-PIB, Poland

Kong, S., Okajima, K., 2016. Diverse photoreceptors and light responses in plants. J. Plant Res. 129, 111-114.

Kopcewicz, J., 1980. Rola fitochormonu we wzroście i rozwoju roślin. Wiad. Bot. 24 /1, 67-84 (in Polish).

Koornneef, M., Bentsink, L., Hilhorst, H., 2002. Seed dormancy and germination. Curr. Opin. Plant Biol. 5, 33-36.

Lau, O.S., Deng, X.W., 2010. Plant hormone signaling lightens up: integrators of light and hormones. Curr. Opin. Plant Biol. 13, 571-577.

Lityński, M., 1982. Dojrzewanie i spoczynek nasion In: Biologiczne podstawy nasiennictwa. Wyd. 2 popr. Lityński, M., (ed.) PWN Warszawa. pp:36-64 (in Polish).

Lityński, M., Urbaniak, Z., 1958. Obserwacje nad wpływem światła na nasiona niektórych gatunków roślin w czasie ich przechowywania. Plant Beed. Seed Sci . (formerly: Hod. Roś. Aklim. Nas. ) 2(1), 21-66.

Masojć, P., Milczarski, P., 2009. Relationship between QTLs for preharvest sprouting and alphaamylase activity in rye grain. Mol. Breed. 23, 75-84.

Munkvold, J.D., Tanaka, J., Benscher, D., Sorrells, M.E., 2009. Mapping quantitative trait loci for preharvest sprouting resistance in white wheat. TAG 119, 1223-1235.

Piskurewicz, U., Turečková, V., Lacombe, E., Lopez-Molina, L., 2009. Far-red light inhibits germination through DELLA-dependent stimulation of ABA synthesis and ABI3 activity. The EMBO J. 28, 2259-2271.

Pokojska, H., Grzelak, K., 1994. Development of dormancy in triticale seeds under field conditions. Plant Beed. Seed Sci . (formerly: Hod. Roś. Aklim. Nas. ) 38 (1/2), 127-135.

Rybka, K., 1994. The structure and properties of grain non-starch polysaccharides. Post. Nauk Roln. 94, 77-87 (in Polish).

Rybka, K., Boros, D., Raczyńska-Bojanowska, K., Rakowska, M., Sawicka-Żukowska, R., Jędrychowska, B., 1988. Viscosity of Rye Grain Components. Mol. Nutr. Food Res. (formerly Nahrung )32, 795-800.

Saulnier, L., Guillon, F., Chateigner-Boutin, A.L., 2012. Cell wall deposition and metabolism in wheat grain. J. Cereal Sci. 56, 91-108. 
Tibbitts, T., Morgan, D., Warrington, I., 1983. Growth of lettuce, spinach, mustard and wheat plants under four combinations of high-pressure sodium, metal halide and Tungsten Halogen Lamps at equal PPFD. J. Am. Soc. Hor. Sci. 108, 622-630.

Warpeha, K.M., Montgomery, B.L., 2016. Light and hormone interactions in the seed-to-seedling transition. Env. Exp. Bot. 121, 56-65. 